\title{
MULTISENSORY DESIGN FOR SENSE OF COHERENCE: A CASE STUDY OF ACADEMICS' WORKSPACES
}

\author{
CASTHER. F. ${ }^{1}$ \& COOREY. S. ${ }^{2}$
}

1,2University of Moratuwa, Moratuwa, Sri Lanka

1'casdfarah@gmail.com, 2scoorey@uom.lk

\begin{abstract}
Multisensory design in workplace plays an important role in the sense of wellbeing and sense of coherence of its users. Both are important for workplace productivity and efficiency. Workplace designs are often driven by maximising capacity and corporate identities rather than the need for improving the quality of environments and sense of wellbeing of its users which is critical for optimising workplace productivity. Multisensory design features vary across workplace environments and the response to such may also vary based on the user groups, their background, cultural differences, type of profession or work being performed etc. The study aims to explore multisensory design in workplace and its impact on sense of wellbeing and coherence of its users in a case study of a workplace of academics in a Higher Education Institution. A qualitative approach is used to collect data on user perceptions via in-depth interviews, memory sketching, visual surveys etc. The workplace multisensory design features are assessed using checklists and photographic observations. Findings show that universal factors such as adequate privacy, availability of biophilia, informal interactions in the workplace and the flexibility for personalisation enhanced sense of wellbeing and coherence in workplace., which led to a positive impact on workplace productivity.in the users.
\end{abstract}

Keywords: Multisensory design: workplace: sense of coherence: sense of wellbeing.

\section{Introduction}

Work is inherently intertwined with an individual's personal life, social connections, and aspirations. Personal well-being can greatly impact how people perform at work, and the physical environments they reside plays a role in enhancing this sense, hindering their work capacity if the environment is unsatisfactory (Croome, 1999). Work performance is impacted by how a person feels; therefore, associative perceptions one holds of a physical workspace ultimately coincide with their sense of well-being. The general definition of an Office is a room, or a set of rooms or a building designated for commercial, professional, or bureaucratic work (Office - Definition of Office by The Free Dictionary, 2016). In truth to this statement, workplaces do generally seek to increase efficiency of employees. Therefore, Associative perceptions of the workplace are usually along the lines of "functional" and "economical".

Christopher Alexander describes work as one of the most salient features of a human, and the artificial separation of life and work creates a gap in life which leads to an individual feeling less alive when at work. He believes, people do have the right to expect an emotionally enriching workplace, and the cost of it is significantly not greater than what it costs to create a dead space and cost cutting by eliminating the need for enrichment could lead to the design of oppressive workspaces(Salingaros, 2011). Acknowledging the physical, mental, social associations one makes during work is important for overall general well-being (Soltani, et al., 2015)

Well-being in the workplace, is not merely the absence of occupational risks, accidents, and diseases. Positive features such as the "quality" of workspace is important. Well-being in the western world's workplaces rests on the continuous co-operation and dialogue in-between individuals or groups in 
an office environment. Safe, healthy, and productive work needs to be coupled with well-led organizational values and a competent workforce (Work community), who can see their jobs as meaningful and rewarding (Ruohomäki et al., 2015) which would lead to better personal motivation with the competence to continue tasks (Clements-Croome et al., 2019).

Studies on workplace user well-being has been studied in terms of quantitative aspects such as illuminance levels on worktops, ambient temperature, air temperature, healthy material usage in interiors etc. Different indexes such as the WELL Building standard have been introduced to measure the qualitative aspects of environment to ensure user well-being. But, many studies tend to overlook the qualitative factors of space which are not quantifiable. (Clements-Croome et al., 2019). Identifies these in his "Flourish" model, which he names the "Sparkle layer" further pointing out that qualitative elements are the most important in terms of enhancing flourish, which is a similar identification of Sense of Well-Being.

(Roskams and Haynes, 2019) had understood sense of wellbeing in terms of increasing Salutogenic potential of space, which is to provide the user with resources to cope with stressful situation in the workplace, which is measured by their individual Sense of Coherence. They produce several strategies to generate such sense.

Although the studies and theoretical modules shows promise in understanding design qualities that much be incorporated to increase well-being in workplaces, there lacks empirical evidence to support how these universal qualities could be implemented in a specific context, as a collective. Further research on workspace that evoke sense of well-being, should seek to turn theoretical knowledge into concrete design solutions that could be used as guiding principles.

\section{Multisensory Design in Workplace}

\subsection{SENSE OF WELL-BEING}

Flourish Model (Clements-Croome et al., 2019): Clements-Croome et al., (2019) studied several design models presented by various authors based on the premise of evoking sense of flourish in a workplace setting.

These models describe a similar construct, which is, that to achieve a sense of flourishing, the space not only should consist of basic and quantitative requirements but sense of space primarily consisting of the qualitative sense of the place, space, social climate, and biophilic design elements.

Human Flourishing concerns itself with positive psychology such as moral values, strengths, and virtues of an individual and how these can be developed in human life.(Boniwell and Zimbardo, 2015). This shows similar construct to the salutogenic model discussed below.

Salutogenic approach to enhance well-being (Roskams \& Haynes, 2019): Primarily implemented in designing healthcare architecture, Salutogenesis is to introduce resources in an environment to increase Health-ease as opposed to combating disease, or pathogenesis, as proposed by (Antonovsky,(1987) as cited in (Roskams \& Haynes, 2019)) An individual's health continuously shifts from health-ease to dis-ease due to everyday stressors and hardships (generalized resistance deficits) while shifting back to health-ease is caused by (generalized resistance resources). This rings true even for office environments mainly focuses at getting rid of pathogenic or harm-causing potentials. This is not sufficient to provide "truly healthy workplaces".

\subsection{WORK ENVIRONMENT AND SENSE OF WELLBEING}

Perceptual understanding occupants have of their office space, is important in work environments. Designing space to accommodate these personal associative understandings contributes to better productivity, satisfaction, and well-being. In this regard, multisensory design plays a key role. ClementsCroome (2019) identifies that designing for the senses can go beyond responding to five senses, and Interoception or sense of self (Self-Awareness) to be the most important sense in terms of well-being, and design should cater to the sense of Interoception. To do so, Clements-Croome (2019) proposed to go beyond standard and user-controlled comfort levels, focusing on spatial qualities such as views on nature, daylight, colour, décor, layout, aesthetics, and green space around building.

Table 1 elaborates on techniques required to bring salutogenic well-being categorized in functional, social, and psychological dimensions. 


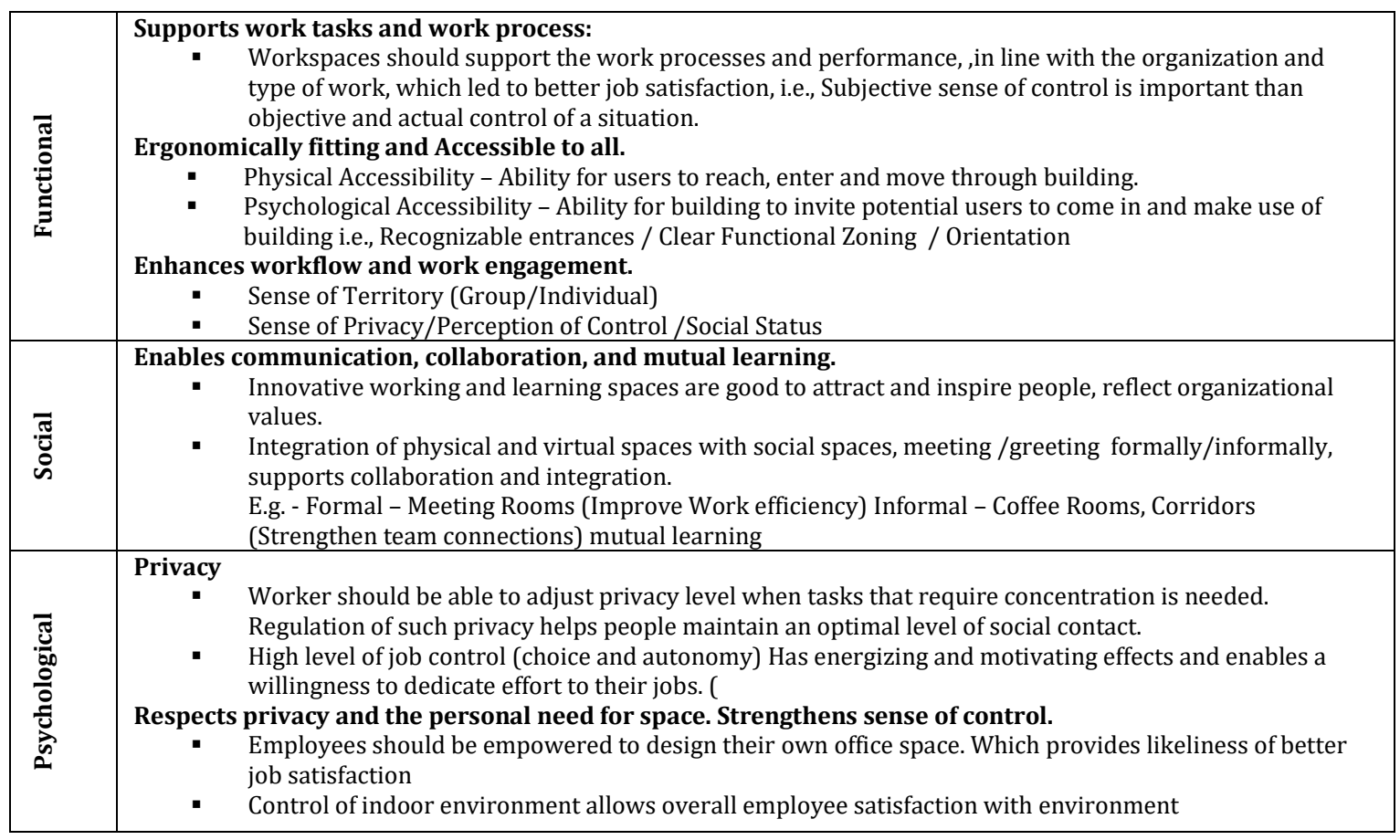

Table 1: Promoting Salutogenic Well-Being Source - (Ruohomäki et al., 2015)

\subsection{SENSE OF COHERENCE}

For environment to bring better psychosocial well-being, an individual's 'sense of coherence' (SOC) identified as an individual's perceptions regarding the events occurring around them. This is key, giving individuals a better ability in handling generalized resistance deficits ((Antonovsky, 1987) (Roskams \& Haynes, 2019)) SOC

\begin{tabular}{|l|c|}
\hline Comprehensibility & Understanding the challenges to face \\
\hline Manageability & Belief that resources to cope with challenge are available \\
\hline Meaningfulness & To be Motivated to cope \\
\hline
\end{tabular}

Table 2 - Sense of Coherence

Source - [Antonovsky, 1987, 1996 as cited in (Ruohomäki, Lahtinen and Reijula, 2015)

Ruohomäki et al., (2015) and Roskams and Haynes (2019) both groups point of several qualities that are needed in workspaces to bring out sense of well-being through the practice of Salutogenesis, as mentioned below.

\subsubsection{Comprehensibility}

Stimuli of the environment needs to be ordered, predictable and explicable as possible, lack thereof could lead to psychological deficit of "learned helplessness" (Evans and Sticker, 2004) as cited in (Roskams \& Haynes, 2019). The following strategies could collectively help increase comprehensibility of space. Roksams \& Haynes (2019) point out through several studies on modern office design that open plan office spaces are increasingly used because they allow flexibility, reduction on setup renovation time and higher accommodation density which saves on building and operational costs, with positive social relations that increases communication among co-workers. In this office setting, lack of personal privacy is the main negative factor, making users feel violated. Activity-based workspaces combats this but having to find a desk to work every day, finding right people to work with, noise and distraction, difficulties in orientation oneself, making People feel burdened with workload. (Ruohomäki et al., 2015)

The following criteria primarily contribute to building Comprehensibility of an office space. 


\begin{tabular}{|l|c|}
\hline \multirow{2}{*}{ Comprehensibility } & Physical Workspace that fits work style \\
\cline { 2 - 2 } & Accessibility of Space \\
\cline { 2 - 2 } & Privacy of Space \\
\hline
\end{tabular}

Table 2-1 Qualities of Built Environment Contributing to Comprehensibility

\subsubsection{Meaningfulness}

Meaningfulness concerns the extent to which experiences are perceived as challenges worthy of investment. (Roskams \& Haynes, 2019). A work experience more in tune with personal values of an individual could offer better sense of meaningfulness to a worker.

\begin{tabular}{|l|c|}
\hline \multirow{2}{*}{ Meaningfulness } & Exhibition of Organizational Purpose within Space \\
\cline { 2 - 2 } & Supporting Personal Identity Expression \\
\cline { 2 - 2 } & Innovation within work Environment \\
\hline
\end{tabular}

Table .2-2 Qualities of Built Environment Contributing to Meaningfulness

\subsubsection{Manageability}

Roskams and Haynes (2019) points out that when the office is highly manageable, the employees easily develop personal competencies. Several Strategies could help increase manageability.

Biophilic Design: High manageability can be achieved through revival from stressful situations. Nature contributes to stress reduction and restores the positive potential of the user and contribute to better health and cognition. A multitude of studied pointed to several objective elements that could be introduced to workspaces such as incorporating sunlight to the workspace, exposing the interior to greenery either by representations of nature such as images or paintings of nature (passive viewing of nature), or by incorporating indoor plants in pots (active viewing of greenery respectively).

Social cohesion in workplace: Personal competencies develop when there is positive social interaction among peers within a workgroup, which contributes better sense of manageability for the user.

Physical activity in the workplace: preventing poor physical health due to demands in deskbased work and reducing sedentary behaviour is beneficial for promoting physical activity.

\begin{tabular}{|l|c|}
\hline \multirow{4}{*}{ Manageability } & Biophilic Design \\
\cline { 2 - 2 } & Enhancing Social Cohesion \\
\cline { 2 - 2 } & Inclusivity of Space \\
\cline { 2 - 2 } & Physical Activity Level \\
\hline
\end{tabular}

Table.2-3 Qualities of Built Environment Contributing to Manageability

\subsection{RESEARCH AIMS AND OBJECTIVES}

The main research aim is to formulate an in depth understanding if the following two opinions on workspace well-being and spatial perception derived through literature, (1) Does universal qualities of well-being do increase sense of well-being in a specific context? and (2) Does associative perceptions one has with a physical workspace coincide with their general sense of personal well-being? 


\subsubsection{Research Objectives}

1. Observing User understanding of Sense of Well-Being in a Selected Case Study Group

2. Understanding User perception of Objects in space with relation to Spatial Qualities that support sense of wellbeing.

3. Comparative Analysis of user's individual sense of well-being and user perception of the design qualities.

\section{Method of Study}

Workplace and user wellbeing have been researched on, in terms of a quantitative approach, but the qualitative approach and focus on qualitative aspects have been overlooked. Therefore, the methodological basis would constitute a multitude of qualitative techniques to understand the role of associative perceptions to objects of space and how they affect the sense of well-being of an individual. Clements Croome et al (2018) identify these in his "Flourish" model, which he names the "Sparkle layer". Roskams \& Haynes (2019) also understood sense of wellbeing in terms of increasing Salutogenic potential of space, which is measured by each person's individual Sense of Coherence (SoC). The study mainly focused on the Roskams and Haynes work, drawing inspiration from several other studies as well. Participatory understanding provides a good method to understand how a user would build associative understanding of the space around them, and therefore it was primarily considered to develop the methodology.

\subsection{DATA COLLECTION}

\subsubsection{Participants}

Participants are chosen from the group of knowledge workers. Academics were the chosen study group, as they contribute to the knowledge base of the country as well as educate the future generations and aids in the endeavor of accumulating, understanding knowledge environments. Knowledge workers also have different work schedules and work demand as opposed to cooperate workers who does a 9 to 5 job; therefore, their workplaces are important to be accessed and understood. The study was limited to observing a sample of 6 academics. A smaller sample size was chosen due to pandemic restrictions of access to workspaces and meeting of staff members, so each participant was chosen from same faculty within the same university as the researcher, also providing better ground for understanding the spatial conditions and gaining better access due to researchers familiarity with spaces.

\subsubsection{Data}

Sense of Coherence of each space was assessed based on the three main subcategories, namely Comprehensibility, Meaningfulness and Manageability. As each category requires certain quality of environment to aid better SoC, physical elements of the built environment were rated by participants based on the how each would contribute their sense of wellbeing, which was then compared with how participants rated their space in terms of comprehensibility manageability and meaningfulness, as shown in table 3. This was achieved in stage 1, as shown in table 4. Stage 2 was used for the researcher to understand qualities of space as shown in table 3 below.

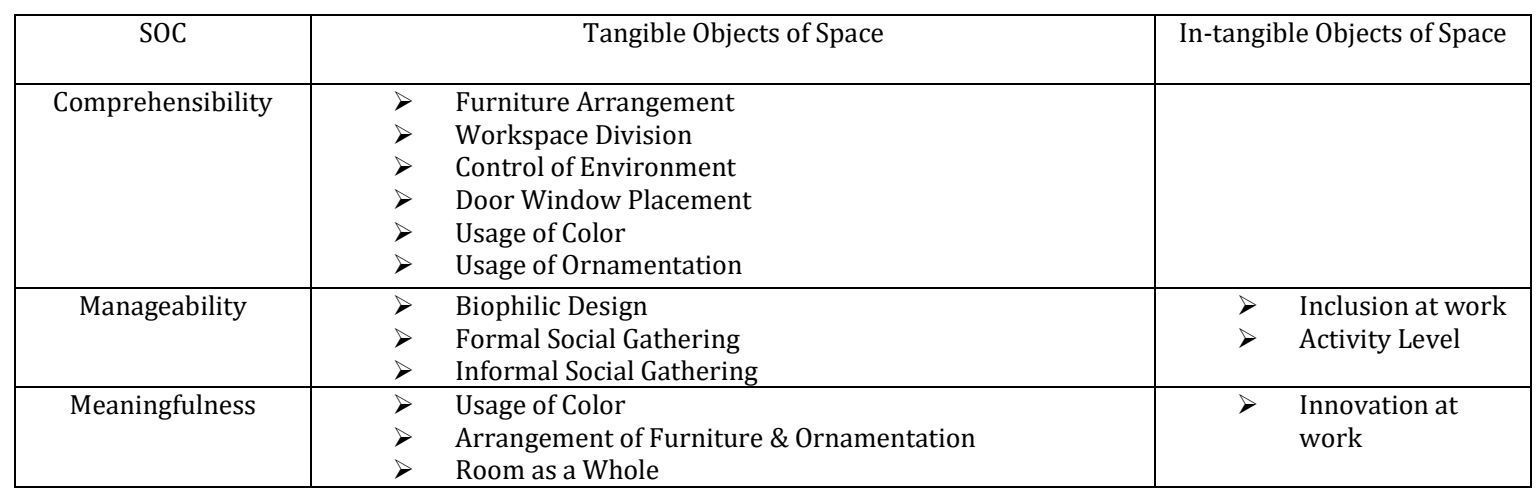

Table 3 Comprehensibility, Manageability \& Meaningfulness assessed in terms of Objects of the Workspace 


\begin{tabular}{|c|c|}
\hline Stage 1 - Memory Sketching & Stage 2 - Visual Survey \\
\hline $\begin{array}{l}\text { Questionnaire: For this stage, a questionnaire with the } \\
\text { following types of assessment was conducted with } \\
\text { participants. } \\
\text { 1. Structured Questions } \\
\text { 2. } \quad \text { Rating Scale } \\
\text { Fixed Rating Scale of Each Space gives } \\
\text { determined values of how the user perceives } \\
\text { each physical parameter of space. } \\
\text { Open Ended Questions - } \\
\text { Have a better perspective of the decisions and } \\
\text { ratings that the participant made in the prior } \\
\text { questioned posed. }\end{array}$ & $\begin{array}{l}\text { Stage } 2 \text { - Visual Survey: As the research will be conducted } \\
\text { with personal within the same academic } \\
\text { institution as the researcher, Visual Data was } \\
\text { collected through photographs. In instances } \\
\text { when that was not possible through user } \\
\text { accounts. } \\
\text { - Photographic Survey } \\
\text { - Researchers' own Experience }\end{array}$ \\
\hline
\end{tabular}

Table 4 - Data Collection Strategies

Following 2 space categories based on location of workspace.

1. Staff Rooms - Within premises of institution

2. Homework Space - Outside premises of the institution / At home of participant

\section{Analysis \& Discussion}

Participant rating of spaces were gathered they were recorded in graphs. Comparison of SoC scores to participant scores of built environments are showed in graphs. Researcher used photographs were used when available to understand space Observations were made on the patterns of the graph that show associations of high overall SOC values with high or low of scores for each space quality. Only the significant observations are discussed in the below tables $5 \& 6$ that summarise the findings.

Staff rooms: These are the workspaces used by staff daily. Participant ratings were provided based on the objects of space as listed in the table. Visual accounts of the space were not obtained therefore findings were based upon interview accounts of space and ratings provided by the users

Home-work spaces: These are the workspaces most of the staffers use when they are not at work, specifically during the time of the pandemic as workspaces in the home environment.

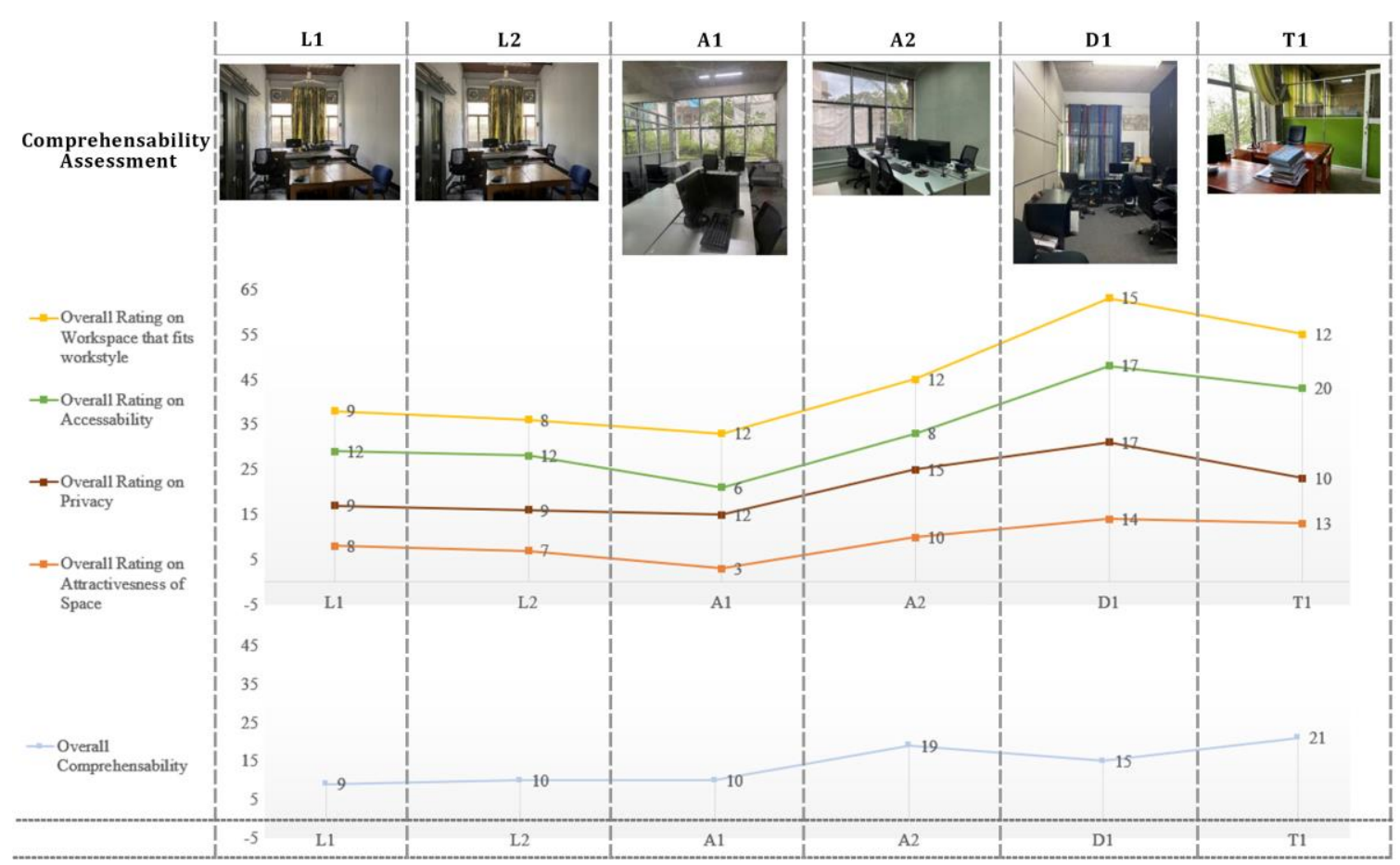

Figure 1 - Comprehensibility Assessment of Office Space 


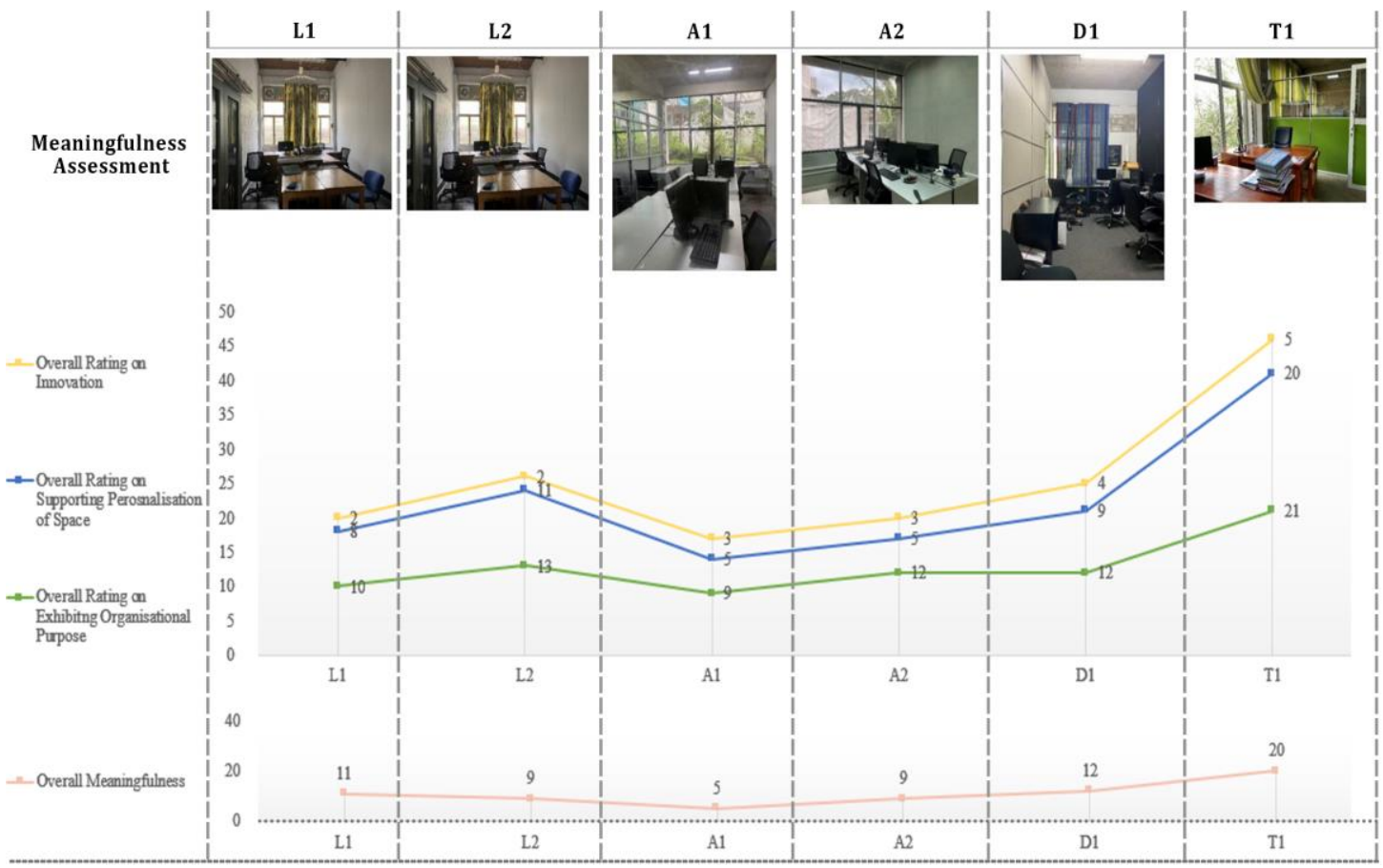

Figure 2 Meaningfulness Assessment of Office Space

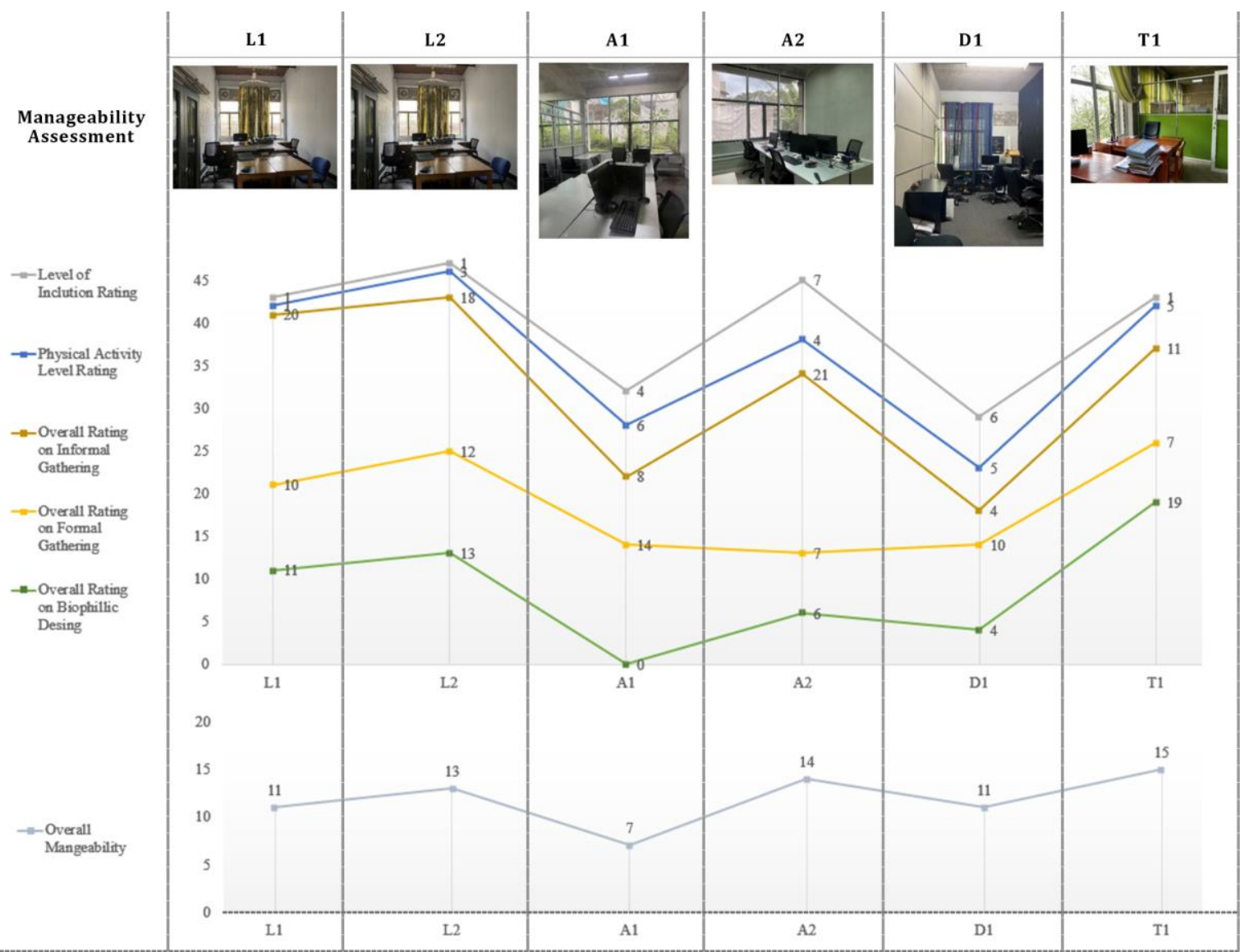

Figure 3 Manageability Assessment of Office Space 


\begin{tabular}{|c|c|c|c|c|}
\hline SOC & $\begin{array}{c}\text { Quality of } \\
\text { Environment }\end{array}$ & $\begin{array}{l}\text { Objects of } \\
\text { Space }\end{array}$ & Analysis & Discussion \\
\hline 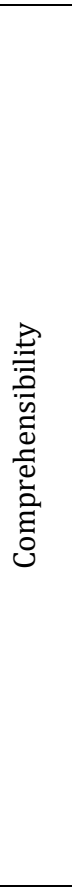 & 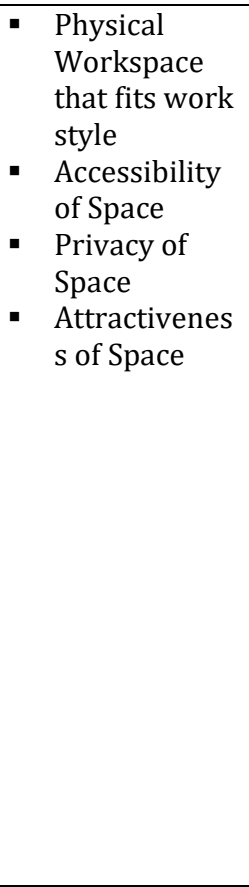 & $\begin{array}{l}\text { Tangible } \\
\text { - Furniture } \\
\text { Arrangement } \\
\text { - Workspace } \\
\text { Division } \\
\text { - Control of } \\
\text { Environment } \\
\text { - Door } \\
\text { Window } \\
\text { Placement } \\
\text { - Usage of } \\
\text { Color } \\
\text { - Usage of } \\
\text { Ornamentati } \\
\text { on }\end{array}$ & $\begin{array}{l}\text { Results show that } \\
\text { high levels of } \\
\text { comprehensibility } \\
\text { are shown when } \\
\text { spaces score high in } \\
\text { - Privacy } \\
\text { - } \quad \text { Accessibility } \\
\text { - } \quad \text { Workplace fits } \\
\text { Attractiveness of the } \\
\text { spaces does not } \\
\text { show an association } \\
\text { with the high } \\
\text { Comprehensibility } \\
\text { scores. }\end{array}$ & $\begin{array}{l}\text { - A Reduced number of people in the } \\
\text { workplace \& Location dependency } \\
\text { increased Comprehensibility. } \\
\text { - Participants did not associate } \\
\text { furniture arrangement with } \\
\text { comprehensibility.. } \\
\text { - Horizontal spatial division between } \\
\text { each work desk space helped. } \\
\text { - Personal Control of Environment } \\
\text { contributed to higher ratings. } \\
\text { - Contribution of Color Usage No } \\
\text { significant change. } \\
\text { - Contribution of Door and Window } \\
\text { Placement in Space Furniture } \\
\text { arrangement to give each person } \\
\text { privacy, especially facing openings } \\
\text { that give views, and center circulation } \\
\text { with workspaces to the corners of the } \\
\text { space contributed to better ratings. }\end{array}$ \\
\hline 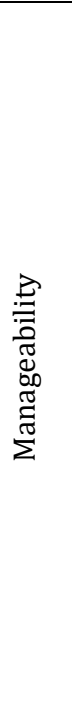 & $\begin{array}{l}\text { - Biophilic } \\
\text { Design } \\
\text { - Enhancing } \\
\text { Social } \\
\text { Cohesion } \\
\text { - Inclusivity of } \\
\text { Space } \\
\text { - Physical } \\
\text { Activity Level }\end{array}$ & $\begin{array}{l}\text { Tangible } \\
\text { - Biophilic } \\
\text { Design } \\
\text { - Formal Social } \\
\text { Gathering } \\
\text { - Informal } \\
\text { Social } \\
\text { Gathering } \\
\text { Intangible } \\
\text { - Inclusion at } \\
\text { work } \\
\text { Activity } \\
\text { Level }\end{array}$ & $\begin{array}{l}\text { Results show that } \\
\text { high levels of } \\
\text { manageability are } \\
\text { shown when spaces } \\
\text { score high in } \\
\text { - Biophilic } \\
\quad \text { Design } \\
\text { - Informal } \\
\quad \text { gathering (As } \\
\text { opposed to } \\
\text { informal } \\
\text { gathering) } \\
\text { Level of Inclusion } \\
\text { and Physical Activity } \\
\text { did not bring } \\
\text { significant } \\
\text { contribution to the } \\
\text { scores. }\end{array}$ & $\begin{array}{l}\text { - Availability of biophilic design such as } \\
\text { colors used (green and brown colors } \\
\text { of wood) and where views of greenery } \\
\text { are significantly visible, and the } \\
\text { participant has given a higher rating } \\
\text { on all accounts. } \\
\text { - Synthetic fabrics and materials } \\
\text { received the lowest ratings. } \\
\text { - Formal discussions did not contribute } \\
\text { significantly to increase manageability. } \\
\text { - Social gathering was subjective to each } \\
\text { participant, based on their view of } \\
\text { individuality, and how they informed } \\
\text { themselves with the space. } \\
\text { - Physical activity levels are also } \\
\text { subjective to the users }\end{array}$ \\
\hline 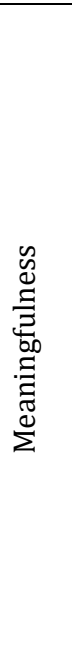 & $\begin{array}{l}\text { - Exhibition of } \\
\text { Organizationa } \\
\text { l Purpose } \\
\text { within Space } \\
\text { - Supporting } \\
\text { Personal } \\
\text { Identity } \\
\text { Expression } \\
\text { - Innovation } \\
\text { within work } \\
\text { Environment }\end{array}$ & $\begin{array}{l}\text { Tangible } \\
\text { - Usage of } \\
\text { Color } \\
\text { - Arrangement } \\
\text { of Furniture } \\
\text { \& } \\
\text { Ornamentati } \\
\text { on } \\
\text { - Room as a } \\
\text { Whole } \\
\text { Intangible } \\
\text { Innovation at } \\
\text { work }\end{array}$ & $\begin{array}{l}\text { Results show that } \\
\text { high levels of } \\
\text { meaningfulness are } \\
\text { shown when spaces } \\
\text { score high in } \\
\text {-Exhibiting } \\
\text { Organizational } \\
\text { Purpose } \\
\text {-Exhibiting } \\
\text { Personal Identity } \\
\text { Expression } \\
\text { Contribution from } \\
\text { Level of Innovation } \\
\text { to overall scores are } \\
\text { far too insignificant. }\end{array}$ & $\begin{array}{l}\text { - Color did not significantly contribute } \\
\text { to the ratings. } \\
\text { - Furniture and Ornamentation } \\
\text { contributes but provides overall lower } \\
\text { ratings. } \\
\text { - The more personalize the space, the } \\
\text { level of innovation has increased. }\end{array}$ \\
\hline
\end{tabular}

Table 5 - SoC levels in office spaces vs Spatial Quality of Office 


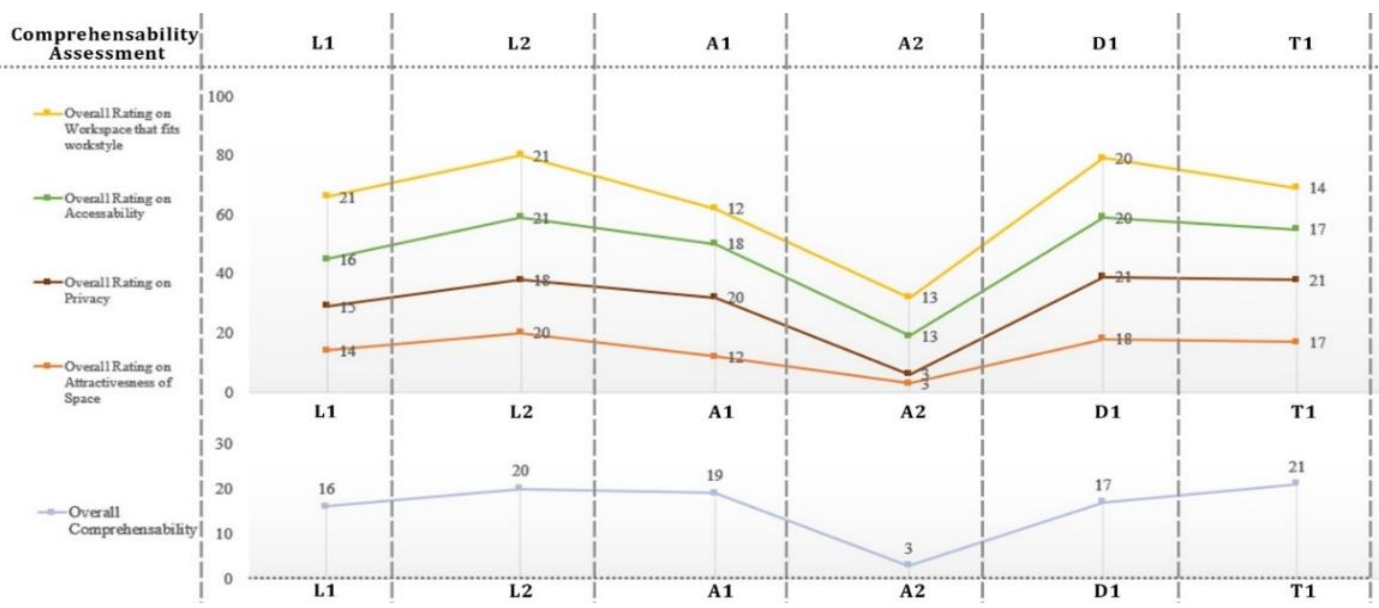

Figure 4 Comprehensibility Assessment of Homework Spaces

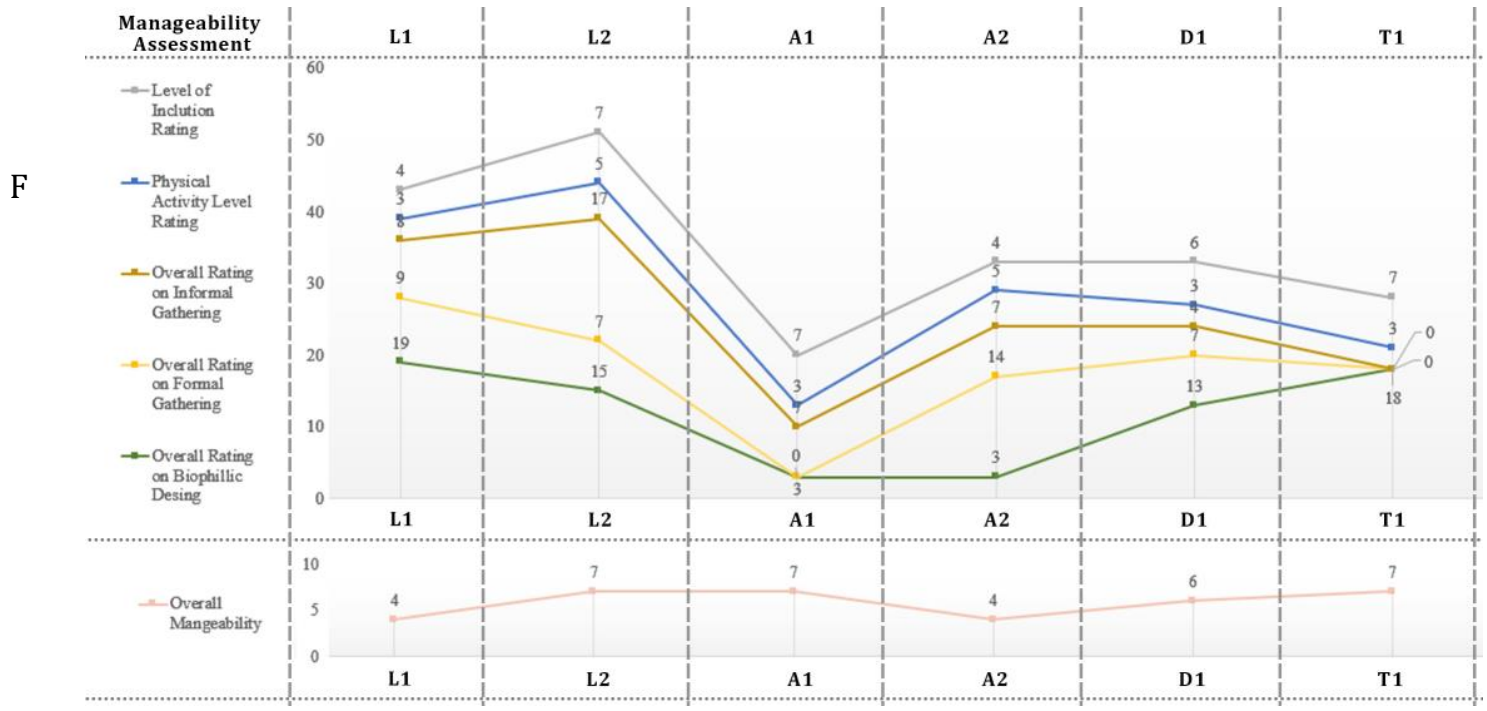

Figure 5 Manageability Assessment of Homework Spaces

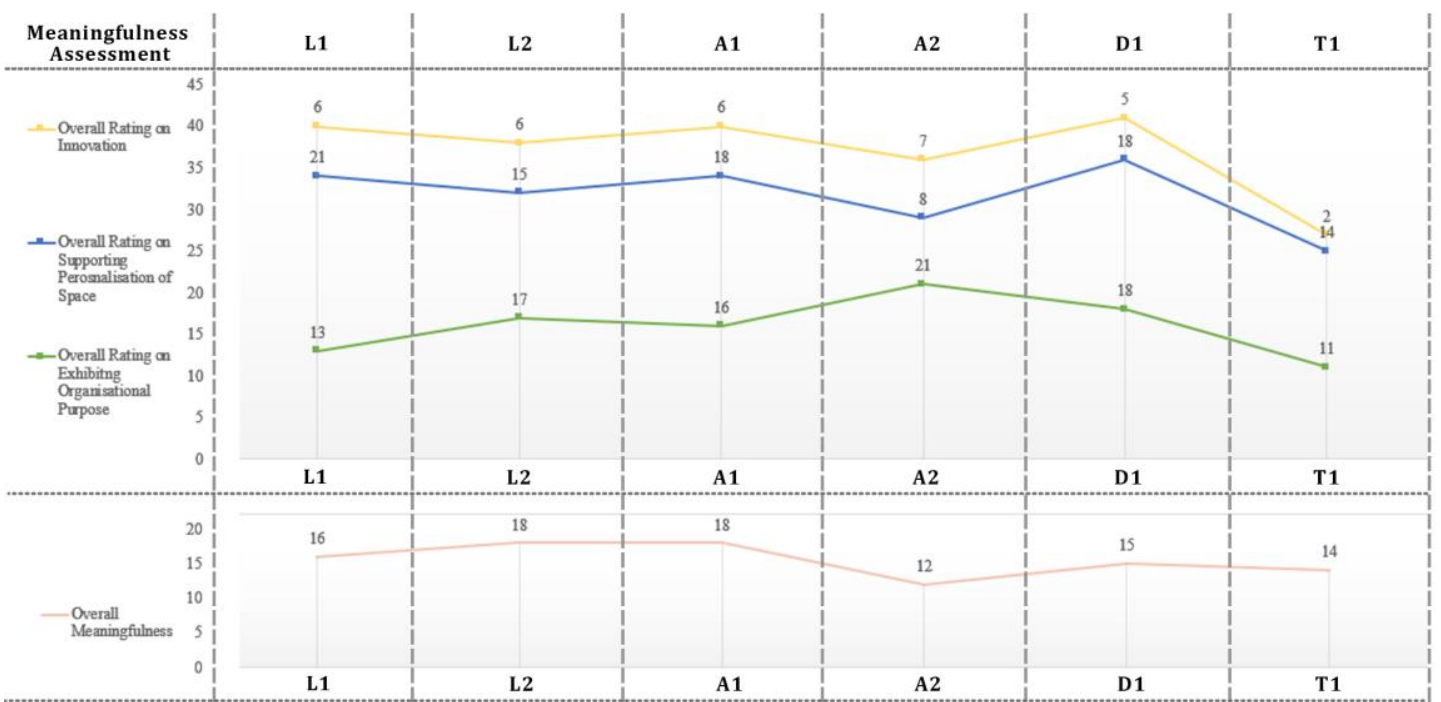

Figure 6 Meaningfulness Assessment of Homework Spaces 


\begin{tabular}{|c|c|c|c|c|}
\hline SOC & Tangible objects & $\begin{array}{c}\text { In-tangible } \\
\text { objects }\end{array}$ & Analysis & Discussion \\
\hline 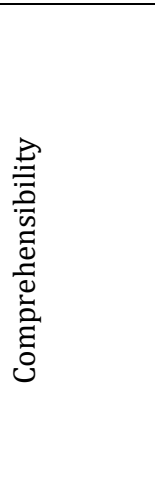 & $\begin{array}{ll}\text { - } & \text { Furniture } \\
\text { Arrangement } & \text { Workspace } \\
\text { Division } & \text { Control of } \\
\text { - } & \text { Environment } \\
\text { Door Window } \\
\text { Placement } \\
\text { - Usage of } \\
\text { Color } \\
\text { Usage of } \\
\text { Ornamentatio } \\
n\end{array}$ & & $\begin{array}{l}\text { Results show that high } \\
\text { levels of } \\
\text { comprehensibility are } \\
\text { shown when spaces score } \\
\text { high in } \\
\text { - Privacy } \\
\text { - Accessibility } \\
\text { - Workplace fits work } \\
\text { - style } \\
\text { - Attractiveness of Space }\end{array}$ & - \\
\hline 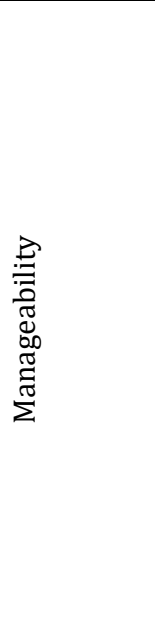 & $\begin{array}{ll}\text { - } & \text { Biophilic } \\
\text { Design } \\
\text { - } & \text { Formal Social } \\
\text { Gathering } \\
\text { - Informal } \\
\text { Social } \\
\text { Gathering }\end{array}$ & $\begin{array}{ll}\text { - } & \text { Inclusion } \\
\text { at work } \\
\text { - } \\
\text { Activity } \\
\text { Level }\end{array}$ & $\begin{array}{l}\text { Results show that high } \\
\text { levels of manageability } \\
\text { are shown when spaces } \\
\text { score high in } \\
\text { - Level of Inclusion } \\
\text { Other factors (Physical } \\
\text { Activity / Informal Social } \\
\text { Gathering / Formal Social } \\
\text { Gathering / Biophilic } \\
\text { Design) vary in rating } \\
\text { therefore direct } \\
\text { relationship could not be } \\
\text { established. }\end{array}$ & $\begin{array}{l}\text { Lack of liveliness is } \\
\text { space and lack } \\
\text { motivation to work } \\
\text { with other colleagues } \\
\text { at one's home } \\
\text { workspace provided } \\
\text { lower ratings of } \\
\text { manageability, } \\
\text { Based on the } \\
\text { participant accounts } \\
\text { homework space are } \\
\text { better for individual } \\
\text { work, therefore } \\
\text { reduced social } \\
\text { interaction was } \\
\text { deemed beneficial to } \\
\text { the participants. }\end{array}$ \\
\hline 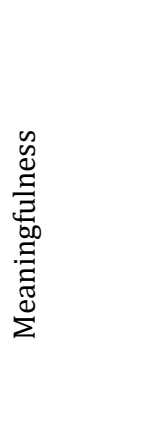 & $\begin{array}{ll}\text { - } & \text { Usage of } \\
\text { Color } \\
\text { - Arrangement } \\
\text { of Furniture } \\
\& \\
\text { Ornamentatio } \\
\mathrm{n} \\
\text { - Room as a } \\
\text { Whole }\end{array}$ & $\begin{array}{l}\text { Innovati } \\
\text { on at } \\
\text { work }\end{array}$ & $\begin{array}{l}\text { Results show that high } \\
\text { levels of meaningfulness } \\
\text { are shown when spaces } \\
\text { score high in } \\
\text {-Exhibiting Personal } \\
\text { Identity Expression } \\
\text { Innovation and exhibiting } \\
\text { organizational purpose } \\
\text { did not show direct } \\
\text { relationship. }\end{array}$ & $\begin{array}{l}\text { Meaningfulness } \\
\text { associations with a } \\
\text { private space is } \\
\text { higher, in terms of } \\
\text { innovation and } \\
\text { inclusion. } \\
\text { Organization purpose } \\
\text { had overall different } \\
\text { ratings that did not } \\
\text { relate with the others. }\end{array}$ \\
\hline
\end{tabular}

Table 6 - SoC levels in home spaces for work vs spatial conditions

\section{Conclusions}

Based on participant accounts, homework spaces were makeshift spaces that many had developed to suite the need of the current conditions. However, these spaces received the highest ratings.

When looking at the data in an overall perspective we can come to the following conclusions

Staff Workspaces - Comprehensibility and manageability showed good relationship but some anomalies were present in the meaningfulness ratings.

Home Workspaces - In home workspaces however, the comprehensibility rating was clear, as well as a good positive relationship in the meaningfulness rating but the manageability rating had significant variations and did not show direct relationship to the factors tested. 
A higher Sense of Coherence is shown with homework spaces more than in the workspaces they used in the university in conjunction with other colleagues within the university. Participant accounts of space suggests the generic nature of spaces in the workplace contributed to this, whereas home spaces allow much better flexibility in crafting a space that really fits their aspirations, work styles etc. On the other hand, certain participants mentioned in personal accounts that they preferred the workspaces within university as opposed to their own home workspaces, but even in these cases their ratings of SoC were higher for their homework space as opposed to spaces outside of it. However, participants found their workspaces at university to be spaces where social interaction happens, and as knowledge workers most found that knowledge sharing was an important part of work, and workspaces were important for that purpose.

Findings mentioned above are in line with Researcher's opinion on associative perceptions one has with the physical workspace coincide with their general sense of personal well-being, especially in cases where the participant could incorporate their own personal aspirations and their archetypal understanding of space, such as when they incorporate an environment like their workspaces at home.

Researcher's opinion on universal qualities of space surmised in the theoretical framework do contribute to sense of well-being in a cross-cultural setting was also in line with the findings.

\section{Limitations and Future Work}

Due to restrictions pertaining to the Covid-19 pandemic and difficulty in locating study participants the selected participants had to be restricted to a single faculty in the same university as the researcher. Most of the data collection methods were done remotely and understanding the lived experience of the participant was difficult and restricted to their verbal accounts of space.

\section{References}

Boniwell, I. and Zimbardo, P. G. (2015) Balancing Time Perspective in Pursuit of Optimal Functioning, Positive Psychology in Practice: Promoting Human Flourishing in Work, Health, Education, and Everyday Life: Second Edition. doi: 10.1002/9781118996874.ch13.

Clements-Croome, D., Turner, B. and Pallaris, K. (2019) 'Flourishing workplaces: a multisensory approach to design and POE', Intelligent Buildings International, 11(3-4), pp. 131-144. doi: 10.1080/17508975.2019.1569491.

Croome, D. (1999) Creating the Productive Workplace, Creating the Productive Workplace. doi: $10.4324 / 9780203027813$.

Marsh, M. and Mueller, K. (2017) 'Multisensory Design: The Empathy-Based Approach to Workplace Wellness', Work Design Magazine. Available at: https://www.workdesign.com/2017/04/multisensory-design-empathybased-approach-workplace-wellness/.

Roskams, M. and Haynes, B. (2019) 'Salutogenic workplace design: A conceptual framework for supporting sense of coherence through environmental resources', Journal of Corporate Real Estate, 22(2), pp. 139-153. doi: 10.1108/JCRE-01-2019-0001.

Ruohomäki, V., Lahtinen, M. and Reijula, K. (2015) 'Salutogenic and user-centred approach for workplace design', Intelligent Buildings International, 7(4), pp. 184-197. doi: 10.1080/17508975.2015.1007911.

Salingaros, N. (2011) 'A new type of work environment: Cristopher Alexander's ideas on office furniture and interiors'.

Soltani, S., Alavi, S. and Ghasr, A. (2015) 'Dwelling in the Workplace: A Contribution to the Phenomenological Attributes of the Workplace', Current World Environment, 10(Special-Issue1), pp. 814-819. doi: 10.12944/cwe.10.special-issue1.98. 